\title{
Identification, biochemical and technological properties of Enterococcus species isolated from raw milk and traditional dairy products
}

\section{Oktay Yerlikaya, Necati Akbulut}

\author{
Ege University, Bornova-Izmir, Turkey
}

Keywords:

Enterococcus spp.

Raw milk

Kefir

Traditional dairy

products

Traditional cheeses

\section{Article history:}

Received 16.04.2020

Received in revised form 01.08.2020

Accepted 27.12.2020

\section{Corresponding}

author:

Oktay Yerlikaya

E-mail:

oktay.yerlikaya@

ege.edu.tr

DOI: $10.24263 / 2304-$

974X-2020-9-4-7

\section{Abstract}

Introduction. The purpose of research was isolation and identification of Enterococcus species from raw milk and traditional dairy products and their biochemical properties were examined. Some biochemical and technological properties of the strains were determined.

Materials and methods. Raw milk and some dairy product samples (Izmir Tulum cheese, Koy cheese, White cheese, butter, Ezine cheese, kefir grain, kefir drink, Armola, Tire Camur cheese, Herby cheese, Goat cheese and Cecil cheese) were collected in different regions of Turkey and samples were inoculated in Kanamycin Aesculin Azide Agar, Slanetz Bartley and M-17 Agar media and Enterococcus spp. were isolated. Acidification properties, exopolysaccharide (EPS) production, lipolytic and proteolytic activity, and decarboxylation activity of Enterococcus strains, which were diagnosed phenotypically and biochemically with different techniques were investigated.

Results and discussion. 167 lactic acid bacteria were identified after Gram staining and catalase tests. Due to the analysis, 122 of these isolates identified as Enterococcus faecium, 18 as Enterococcus durans, 17 as Enterococcus faecalis, 8 as Enterococcus faecium var. and 2 as Enterococcus hirae. Some biochemical and technological properties of these species were studied. It was determined that E. faecium and E. faecalis strains produced higher acidity compared to $E$. durans and $E$. hirae, a total of 19 strains were capable of producing EPS, while 9 strains showed poor EPS production. Also, it was performed $17 \mathrm{E}$. faecium, 2 E. faecalis, 1 E. durans and 1 E. hirae strains showed lipolytic activity and 95 E. faecium, 12 E. durans, 5 E. faecalis var., 3 E. faecalis and 2 E. hirae decarboxylated to lysine and ornithine amino acids. It was observed that Enterococcus spp. isolated from raw milk and traditional dairy products showed differences especially technological characteristics according to the source, species and strain.

Conclusions. Raw milk and dairy products are important source for isolation of enterococci species. The characteristics of Enterococcus species such as acidification, exopolysaccharide production ability, proteolytic and lipolytic activity, decarboxylase activity differed by species and strain. 


\section{Introduction}

Lactic acid bacteria (LAB) are considered to be industrially important microorganisms because of their benefits in human health and nutrition and their fermentation ability. LAB are Gram-positive, prokaryotic bacteria identified as lactic acid productions as the final product. These bacteria are characterized by turning glucose into lactic acid. LAB generally include Lactobacillus, Pediococcus, Leuconostoc and Streptococcus species [1, 2]. Unlike other lactic acid bacteria, enterococci are not GRAS (generally recognized as safe) status, and their presence in water is considered to be an indicator of faecal contamination. However, enterococci are one of the lactic acid bacteria that have an important place in the fermented food industry due to their functional properties, production of lactic acid, proteolysis and lipolytic activities, citrate metabolism, probiotic properties and their ability to synthesize proteins with antimicrobial activity such as bacteriocin production [3, 4]. Enterococci are Gram positive cocci found in single, double or short chains. Until recently, they have been classified in the genus Streptococcus. Streptococcus faecalis was identified by Andrewes and Horder in 1906, and Streptococcus faecium in 1919 by Orla-Jensen [5, 6].

As a result of molecular studies carried out by Schleifer and Kilpper-Balz in 1984, it was suggested that $S$. faecalis and $S$. faecium should be separated from streptococci and transferred to the genus Enterococcus. Then the bacteria in this genus are E. faecalis, E. faecium, E. durans, E. avium, E. casseliflavus, E. malodoratus, E. hirae, E. gallinarum, E. mundtii, E. raffinosus, E. pseudoavium and they are divided into several species such as $E$. flavescens, E. dispar, E. sulfureus, E. saccharolyticus, E. columbae and E. cecorum [7, 8]. In some literatures, it is reported that $E$. durans and $E$. faecium are the same species $[9,10]$. Devriese and Pot [11] gave E. durans within the group of $E$. faecium species consisting of $E$. faecium, E. durans, E. hirae and E. mundtii. In recent identification studies, E. durans and $E$. faecium are mentioned as two separate species [12-15].

Although the use of Enterococcus species may be a controversial issue, certain Enterococcus species can be used as probiotic, starter, and protective cultures, even as food and feed supplements [3, 4]. Studies have generally been carried out by focusing on some species of Enterococcus genera. Although there are studies on Enterococcus species isolated from traditional dairy products, as in our study, there are limited studies mainly on those isolated from Izmir Tulum Cheese. Also, studies on examining the technological properties of different species and strains are limited.

The purpose of research is isolation and identification of Enterococcus species from raw milk and traditional dairy products and their biochemical and technological properties of the strains were determined.

\section{Materials and methods}

\section{Isolation of Enterococcus species}

In aseptic conditions, $10 \mathrm{~g}$ and / or $10 \mathrm{~mL}$ sample was weighed into a sterile stomacher bag and $90 \mathrm{ml}$ of $0.1 \%$ sterile peptone water solution was added. It was homogenized for two minutes using Stomacher (Colworth 400, UK) and $1 \mathrm{ml}$ was taken from this mixture and added to $9 \mathrm{ml}$ of $0.1 \%$ sterile peptone water (Merck, Germany) solution and mixed. Dilution series were prepared by taking $1 \mathrm{ml}$ of the previous dilutions. From the selected dilutions, inoculation was performed using Kanamycin Aesculin Azide Agar (Merck, Germany), Slanetz Bartley Medium (Merck, Germany) and M-17 Agar (Merck, Germany). Petri dishes 
were incubated at $37^{\circ} \mathrm{C}$ for $24-48$ hours under aerobic conditions, and the colonies that were considered to be Enterococcus species, which were thought to be Enterococcus species, were taken with the help of the essence and each colony was transferred to Kanamycin Esculin Azide Broth (Lab M, UK). The medium was inoculated and left for incubation at $37{ }^{\circ} \mathrm{C}$. At the end of the incubation, Kanamycin Esculin Azide Agar was transferred by using the line cultivation method using the medium. Thus, isolates were purified, and purified colonies were transferred to M-17 Broth (Merck, Germany). Gram staining and catalase tests were performed in all isolates before being included in the diagnosis. The isolates which were determined to be Gram positive catalase negative and classified according to their morphology were transferred to M-17 Broth (Merck, Germany) medium containing 20\% glycerol and stored at $-20^{\circ} \mathrm{C}$. For this, M-17 broth $+500 \mu$ active bacteria culture containing $500 \mu \mathrm{l}, 40 \%$ glycerol (AppliChem, Germany) was taken into the eppendorf tube. The medium and glycerol were autoclaved in separate bottles $\left(121^{\circ} \mathrm{C} 15 \mathrm{~min}\right)$ and mixed sterile before use.

\section{Phenotypic and biochemical identification}

Phenotypic identification of Enterococcus species was carried out by modifying the diagnostic stages of Reuter [16]. Enterococcus faecium B-2354, Enterococcus casseliflavus B-3502, Enterococcus faecalis ATCC 29212, Enterococcus hirae UWWE 3080, Enterococcus hirae UWWE 3102 and Enterococcus durans GE-66 were used as reference cultures for the identification of bacteria. In order to identify Gram-positive catalase negative cocci at the level of species, development at different temperatures (at 10,40 and $45^{\circ} \mathrm{C}$ ), development at different salt concentrations (2, 4 and 6.5\%), development at $\mathrm{pH}$ 9.6, formation of ammonia from arginine, and hydrolyse of esculin. In addition to tests such as shredding, various carbohydrates fermenting tests were performed. 13 different carbohydrates were used for this (Lactose, Fructose, Galactose, Maltose, Melibiose, Salicin, Sucrose, Sorbitol, Raffinose, Arabinose, Mannitol, Trehalose and Inulin). Diagnostic tests were carried out by inoculating $1 \%$ of each bacterial culture incubated at $37{ }^{\circ} \mathrm{C}$ for $18-24$ hours on M-17 medium. Except for those for temperature tests, tubes were incubated at 37 ${ }^{\circ} \mathrm{C}$ at the temperature at which the inoculated bacteria were isolated, examined at 24 hours, 48 hours, days 5 and 7 , reactions were recorded as positive or negative.

\section{Identification with API test kits}

Among the strains that could not be identified by traditional diagnostic stages, have problems or appear suspicious, diagnostics were made using API ${ }^{2} 20$ Strep test kits. API ${ }^{\circledR}$ 20 Strep (BioMérieux, France). API ${ }^{\circledR} 20$ Strep is a standardized method that combines 20 chemical tests with a large capacity. It provides the identification of many streptococci and enterococci at the group or species level. The reactions that occur are read according to the "reading table" and the diagnosis is carried out using the analytical profile index or a computerized diagnostic program. The API ${ }^{2} 20$ Strep test was performed as follows: The prepared M-17 agar (Merck, Germany) was poured into petri dishes and solidified. Each isolate was streaked on the surface of the medium in a separate petri dish. Colonies developing in petri dishes incubated at $37^{\circ} \mathrm{C}$ for 24 hours were inoculated into test strips by applying the procedure steps described in the user manual of API ${ }^{\circledR} 20$ Strep. A separate strip was used for each isolate. Strips were incubated at $37^{\circ} \mathrm{C}$. They were checked at the $4^{\text {th }}$ and $24^{\text {th }}$ hours of the incubation as specified in the instructions for use. The resulting changes were recorded and the results were evaluated using the diagnostic program (Apiweb ${ }^{\circledR}$ standalone V 1.1.0, BioMérieux). 


\section{Determination of technological properties}

Acidification. The amount of lactic acid and $\mathrm{pH}$ changes occurring as a result of 24hour incubation in skim milk containing 10\% non-fat dry matter (reconstituted skim milk) were determined at the $3^{\text {rd }}, 6^{\text {th }}, 9^{\text {th }}$ and $24^{\text {th }}$ hours after inoculation [17].

Exopolysaccharide (EPS) production. Using the method specified by Rasic and Kurmann [18], the ability of strains to produce EPS was determined. To this end, M-17 containing double-force lactose and MRS agar medium containing double-force glucose were extracted from active cultures, and streaked colonies were performed, and colonies that creep at the end of the 48-hour incubation period were examined.

Lipolytic activity. Lipolytic activities of the strains were determined using Tributyrin Agar (Merck, Germany) containing Neutral tributyrin (Glycerol tributyrate; Merck). 10 $\mu \mathrm{L}$ cell suspension was spotted on the petri dish and the petri dishes were incubated at $30{ }^{\circ} \mathrm{C}$ for 5 days. Lipolysis was determined by pouring $10 \mathrm{~mL}$ of saturated copper sulphate solution onto the petri dish, and around the colonies being green blue [19, 20].

Proteolytic activity. Proteolytic activity of strains was performed according to Church et al. [21]. $3 \mathrm{~mL}$ o-phthaldialdehyde (Sigma-Aldrich, USA) reagent was added to $150 \mu \mathrm{L}$ TCA filtrate and $5 \mathrm{sec}$. mixed 2 minutes at room temperature. The absorbance at $340 \mathrm{~nm}$ wavelength was read in the spectrometer Spekol-1300 (Analytik Jena, Germany) until the waiting time. Values are given as OPA (o-phthaldialdehyde) equivalent.

Decarboxylase activity. The ability of amino acids to produce biogenic amines by decarboxylation was tested using the media specified by Bover-Cid and Holzapfel [22], which contain any of the lysine and ornithine amino acids. In order to promote decarboxylase activity, strains were sub-cultured 2 times in M-17 broth (Merck, Germany) containing $0.1 \%$ precursor amino acid [23]. Active cultures were inoculated with $0.5 \%$ of Moeller decarboxylase Broth containing control, lysine and ornithine. The yellow color decarboxylation (-), which was formed by comparison with the control sample at the end of the 48 hour incubation, was evaluated as purple color decarboxylation $(+)$. Escherichia coli O157: H7 ATCC 8739 reference strain was used as positive control in the study [24].

\section{Results and discussion}

\section{Physiological and biochemical diagnostic results of Enterococcus species}

As a result of Gram staining, catalase test and morphological examinations, a total of 167 isolates with Gram positive, catalase negative and cocci appearance were taken into various physiological and biochemical tests. Traditional methods were compared with API test results and those that were compliant were analysed further. Strains were named by coding K: the source of isolation and E: the strain number (Table 1). 
Isolate codes of isolated Enterococcus species and their isolation sources

\begin{tabular}{|l|l|}
\hline Isolate codes & Isolation sources \\
\hline $\begin{array}{l}\text { K1, K2, K3, K5, K7, K8, K11, K12, K13, K15, K16, K17, K65, } \\
\text { K73, K74, K75, K78, K79 }\end{array}$ & Izmir Tulum Cheese \\
\hline K60, K69, K70, K71 & Raw milk \\
\hline K18, K63, K76 & Fresh Cheese \\
\hline K67, K80 & White Cheese \\
\hline K51, K62 & Butter \\
\hline K40 & Armola Cheese \\
\hline K41 & Tire Mud Cheese \\
\hline K50 & Kefir grain \\
\hline K61 & Kefir drink \\
\hline K64 & Whey cheese \\
\hline K66 & Herby Cheese \\
\hline K68 & Ezine Cheese \\
\hline K72 & Cecil Cheese \\
\hline K77 & Goat cheese \\
\hline
\end{tabular}

As a result of the comparison and evaluation, 122 isolates were E. faecium $(73.05 \%)$, 18 isolates were $E$. durans (10.78\%), 17 isolates were $E$. faecalis $(10.18 \%), 8$ isolates were E. faecalis. $(4.79 \%)$ and 2 isolates were E. hirae $(1.19 \%)$. Sources of isolation are given in Table 1. In the differentiation of Enterococcus species, sugars such as sorbitol, arabinose, mannitol and raffinose and changes in different temperature and salt concentrations were taken into consideration. These saccharides are reported to be critical sugars in the separation of E. faecium, E. durans and E. hirae species. Besides these saccharides, fermentation tests using sugars such as trehalose, lactose, fructose, galactose, maltose, mellobiose, salicin, sucrose and inulin helped in definitive diagnosis $[25,26]$.

In some literatures, E. durans and E. faecium are reported as the same species $[9,10]$. Devriese and Pot [11] gave $E$. durans within the group of $E$. faecium species, consisting of E. faecium, E. durans, E. hirae and E. mundtii. In recent identification studies, E. durans and E. faecium are mentioned as two separate species [12-14]. Although it is stated in many research and literature that Enterococcus species develop at 6.5\% salt concentration, the results obtained in the study show that there are strains that can develop in maximum $4 \%$ salt concentration. Similar results have been revealed by Guley [15]. Only reference strains of $E$. casseliflavus inulin $(+)$ reacted, while only 2 of the E. faecium isolates gave a weak inulin reaction. E. faecium isolates gave variable reactions in terms of melibiose, raffinose and sucrose. Their ability to ferment sugar in question varies from strain to strain. Some strains of E. faecium, on the other hand, suggested that there was a mistake in the diagnosis of bacteria since mannitol gave a negative reaction, and it was concluded that this species may be a variant of $E$. faecium by making a detailed literature scan as a result of repeated positive reactions in repeated controls [11, 15, 25, 28,29]. 


\section{Acidification}

Enterococcus species showed different acidification results depending on isolation source, species and strain differences. While some species produced high acidity, some species showed low acidity. When the isolated species were examined, E. faecium and E. faecalis strains produced higher acidity compared to $E$. durans and E. hirae, but some $E$. faecium strains formed low acidity and some E. hirae strains had some E. faecium. It can be seen that it can produce higher lactic acid than strains. In the medium of $E$. faecium strains containing $10 \%$ skim milk powder, $\mathrm{pH}$ values changed between 5.80 and 6.64 hours at the $3^{\text {rd }}$ hour, while the amount of lactic acid (LA) occurred in the lowest $(0.108 \%)$ K69E2 strain and highest in the K80E4 strain $(0.468 \%)$. At the end of the 24 hour incubation, $\mathrm{pH}$ values ranged from 4.10 to 5.12, while the lowest lactic acid amount was determined in the K1E1 strain with $0.230 \%$, while the highest was determined in the K5E2 strain with $0.932 \%$. The $\mathrm{pH}$ values of $E$. durans strains were changed between 6.07 and 6.55 at the $3^{\text {rd }}$ hour, while the amount of lactic acid formed was determined in the K63E1 strain with the lowest amount of $0.120 \%$ LA, while the highest was determined in the strain of $0.257 \%$ LA K7E2. At the end of the 24-hour incubation, $\mathrm{pH}$ values ranged from 4.06 to 5.38, while the lowest LA amount was determined in the K40E4 strain with $0.293 \%$, while the highest was determined in the $\mathrm{K} 75 \mathrm{E} 1$ strain with $0.859 \%$. When looking at the $\mathrm{pH}$ decreasing properties of E. faecalis strains at the $3^{\text {rd }}$ hour, it is seen that the values vary between $6,12-6,57$, the amount of lactic acid occurring is determined in the K41E2 strain with the lowest amount of lactic acid K5E1 with the lowest $0.112 \%$. At the end of the $24 \mathrm{~h}$ incubation, $\mathrm{pH}$ values ranged from 4.16 to 4.94, while the lowest lactic acid amount was determined in the K64E2 strain with $0.315 \%$, while it was observed in the K5E1 strain with the highest $0.99 \%$.

The $\mathrm{pH}$ value of the isolated $2 \mathrm{E}$. hirae strains were determined as at $3^{\text {th }}$ hour $6.42 \mathrm{in}$ K17E2 strain and 5.82 in K73E5 strain. The amount of lactic acid produced by the isolates was determined as $0.199 \%$ in K17E2 strain and $0.170 \%$ in K73E5 strain. At the end of the $24 \mathrm{~h}$ incubation, it was observed that the K17E2 strain was higher (5.95) and the K73E5 strain was lower (4.74) as in the $3^{\text {rd }}$ hour. Lactic acid amounts were determined as $0.504 \%$ and $0.890 \%$ in these strains. Acidification is an important criterion in the selection of starter cultures to be used in cheese production. Tuncer [30] determined that E. faecium strains showed higher acidification than E. faecalis and E. durans in Enterococcus species isolated from Tulum Cheese. On the other hand, it has been revealed by some researchers such as Dagdemir and Ozdemir [31], Suzzi et al. [32] some E. faecalis strains have higher acidification power than E. faecium and E. durans.

\section{Exopolysaccharide (EPS) production}

Some lactic acid bacteria can form sticky, lysing agents. This feature of bacteria is revealed by mutation, that is, the permanent character and structure change that occurs in the organism. Sometimes there are development conditions that increase the production of these substances. These conditions can be listed as too high or too low development temperature, lack of nutrients in the culture of the culture, separation of strains in mixed cultures, high $\mathrm{pH}$ and lyophilization [9]. In the study, it was determined that a total of 19 strains were capable of producing EPS, while 9 strains showed poor EPS production. When the distribution of EPS producing Enterococcus species and strains is examined, there are 15 E. faecium, 2 E. durans and 2 E. faecalis has been in the formation. Any E. faecalis strains produced EPS. The distribution of the species and strains that have poor EPS production ability were $6 E$. faecium, 1 E. durans and 2 E. faecalis. There are a limited number of studies conducted with 
exopolysaccharide production of Enterococcus species. Jamaly [33] determined that all 23 E. durans strains isolated from Moroccan dairy products are capable of producing EPS. Omafuvbe and Enyioha [34] determined that 1 of the 2 strains of E. faecalis isolated from yogurts consumed in Nigeria is capable of producing higher EPS than Lactobacillus, Streptococcus and Lactococcus species.

\section{Lipolitic activity}

Lipolysis is the phenomenon of hydrolysis of lipids under the influence of lipolytic enzymes such as lipase and breaking down into fatty acids with glycerine, the building blocks. The lipase enzyme can be milk-specific, of natural or microbial origin. Generally, lactic acid bacteria have a weak level of lipolytic activity and are more effective on monoand diglycerides. Lipolysis is a desired feature for some cheese types to gain their desired qualities [10].

Fatty acids directly affect the flavor of many cheese types. Especially C4 (butyric acid) - C10 (caproic acid) acids have strong flavor (rancid, sharp, goat, soapy, coconut-like). The amount of fatty acids varies widely between varieties. In addition to its direct effects on cheese flavor, fatty acids act as pioneers in the production of other volatile flavor compounds during ripening [35]. Among the Enterococcus species and strains in the study, 17 E. faecium, 2 E. faecalis, 1 E. durans and 1 E. hirae strains showed lipolytic activity. There are contradictory data and statements regarding the lipolytic activities of Enterococcus species in the literature. Suzzi et al. [32] reported that while strains of different species did not observe lipolytic activity, Durlu-Ozkaya [36] reported that E. faecalis hydrolysed milk triglycerides at a higher level than E. faecium and E. durans.

\section{Proteolytic activity}

Proteolytic activity is the hydrolysis of proteins by proteolytic enzymes of natural or microbial origin. Proteolytic activity is important both in terms of acid forming function of starter cultures and sensory properties of the product. In research, it has been determined that lactic acid production and proteolytic activity differ between genus, species and strains in lactic acid bacteria [37]. In the study, isolates with different characteristics and high activity under development conditions were evaluated, and strains that could not survive were excluded.

It is seen that E. faecium strains constitute the majority of the tested species and their proteolytic activities vary between $0.21-0.50$ as OPA values. OPA values varied between $0.28-0.49$ for E. durans strains and $0.21-0.48$ for E. hirae strains. There is E. faecalis taken to the test. The value of the strain was determined as 0.41 , while the reference was determined as 0.23 in the strain of E. casseliflavus. It has been revealed by many studies that the proteolytic activity of enterococci varies depending on the source, species and strain. Wallace and Harmon [38] studied the intracellular protease of an E. durans strain and determined that the protease produced was particularly active against casein and $\beta$-lactoglobulin and did not hydrolyse bovine serum albumin. Dovat et al. [39] studied the proteolytic activity of enterococci in milk and demonstrated that they exhibit low proteolytic activity. Carrasco de Mendoza et al. [40] found that Enterococcus strain used sodium caseinate as a substrate in determining the extracellular proteolytic activity, proteolytic activity may change depending on strain and time, and after 48 hours incubation, this situation became more evident after 120 hours of incubation. Wessels et al. [41] found that total 108 E. faecium, E. faecalis and E. durans strain isolated from various dairy products developed under cold conditions and 
showed proteolytic activity. Villani and Coppola [42] examined the proteolytic activity of 24 E. faecium and $60 \mathrm{E}$. faecalis strains in skim milk at $37{ }^{\circ} \mathrm{C}$ for 6 hours after incubation, and all E. faecalis strains were more proteolytic compared to E. faecium strains. Andrighetto et al. [43] revealed in their study on 124 Enterococcus species isolated from traditional Italian cheeses, showing that they showed weak proteolytic activity in milk and 30 more strains including E. faecalis strains were proteolytic. Sarantinopoulos et al. [44] 129 E. faecium, E. durans and E. faecalis strains showed low extracellular proteolytic activity and E. faecalis strains were more proteolytic.

\section{Decarboxylation activity}

Decarboxylation of amino acids by bacteria has been linked to their ability to produce biogenic amines. It was performed on $95 \mathrm{E}$. faecium, $12 \mathrm{E}$. durans, 5 E. faecalis var., $3 \mathrm{E}$. faecalis and 2 E. hirae among the Enterococcus species, which were decarboxylated using lysine and ornithine amino acids. A total of $91 \mathrm{E}$. faecium strains were found to decarboxylated to ornithine of 21,8 of them were lysine, and 5 of them were decarboxylated together with both amino acids. There are 5 E. faecalis and 12 E. durans strains, 2 of them are both lysine and ornithine, 2 strain decarboxylated only ornithine. None of the E. faecalis and E. hirae strains gave decarboxylation positive results. Sarantinopoulos et al. [44] determined that none of the strains decarboxylated lysine or ornithine in their study on 129 Enterococcus strains (E. faecium, E. faecalis and E. durans). Tuncer [30] found that none of the 39 Enterococcus species and strains isolated and identified from Turkish Tulum type cheese decarboxylated lysine or ornithine. Yousif et al. [45] revealed that none of the $22 E$. faecium isolates isolated from African fermented sorghum products decarboxylated lysine and ornithine. Hassaïne et al. [46] determined that the Enterococcus species isolated from raw milk samples do not decarboxylased lysine and ornithine. Belgacem et al. [47] found that none of the 24 strains of E. faecium isolated from Gueddid, a traditional fermented meat product, decarboxylated lysine and ornithine. Omafuvbe and Enyioha [48] determined that 2 strains of $E$. faecalis isolated from yoghurts consumed in Nigeria decarboxylated lysine and ornithine.

\section{Conclusions}

As a result of the research, Enterococcus species and strain with different biochemical properties and technological characteristics were isolated and diagnosed. In the study, it was observed that Enterococcus spp. showed differences according to the source, species and strain from which the technological features were isolated. In future studies, it will also be useful to investigate whether enterococci species isolated from traditional dairy products have different aroma substances, their amount of forming exopolysaccharide and whether they have mutagenic effects. Thus, by using the culture catalogues of the species and strains that will not pose a problem for human health, there will be many Enterococcus species and strains with different characteristics in these catalogues, and their use in different types of dairy products can be easily tested.

\section{Acknowledgements}

This study is supported by Ege University Scientific Research Projects Coordination Unit (Project Number: 2011-ZRF-010). 


\section{References}

1. Salminen S., Deighton M.A., Benno Y., Gorbach S.L. (1998), Lactic acid bacteria in health and disease. In: Salminen S, von Wright A, eds. Lactic Acid Bacteria: Microbiology and Functional Aspects. 2nd ed. New York: Marcel Dekker Inc, 211-54.

2. Kongo J.M. (2013), Lactic acid bacteria as starter-cultures for cheese Processing: Past, present and future developments; Lactic Acid Bacteria - R \& D for Food, Health and Livestock Purposes, pp. 3-22.

3. Franz C.M., Holzapfel W.H., Stiles M.E. (1999), Enterococci at the crossroads of food safety?, International Journal of Food Microbiology, 47(1-2), pp. 1-24.

4. Ogier J.-C., Serror P. (2008), Safety assessment of dairy microorganism: the Enterococcus genus, International Journal of Food Microbiology, 126, pp. 291-301.

5. Lebreton F., Willems R.J.L., Gilmore M.S. (2014), Enterococcus diversity, origins in nature, and gut colonization. Enterococci: From commensals to leading causes of drug resistant infection. Ed: Gilmore, M.S., Clewell, D.B., Ike, Y., Shankar, N., Boston.

6. Toit M.D., Huch M., Cho G.S., Franz C.M. (2014), The genus Streptococcus, In: Lactic Acid Bacteria: Biodiversity and Taxonomy, Holzapfel, W.H., Wood, B.J.B., Eds: John Wiley \& Sons, pp. 457-505.

7. Facklam R.R., Teixeria L.M. (1998), Enterococcus. In: Topley and Wilson "s Microbiology and Microbial Infections, Collier L, Balows A, Sussman M (eds)., Vol 2 (Systematic Bacteriology). $9^{\text {th }}$ edition, Edward Arnold, London, pp. 669-682.

8. Koneman E.W., Allen S.D., Janda W.M., Schreckenberger P.C., Koneman EW., Allen S.D., Janda NM., Schreckemberger P.C., Winm Jr W.C. (2005), Diagnosticdo Microbiologico: Texto e Atlas Colorido. $5^{\text {th }}$. Edition, Medir, Rio de Janeiro, 1465 pp. (in Portuguese Brazilian)

9. Yaygın H., Kilic S. (1993), Süt Endüstrisinde Saf Kültür, Altındă̆ Matbaacılı, İzmir (in Turkish)

10. Kilic S. (2001), Süt Endüstrisinde Laktik Asit Bakterileri, Ege Üniversitesi Ziraat Fakültesi Yayınları, No: 542, İzmir. (in Turkish)

11. Devriese L.A., Pot B. (1995), The genus Enterococcus B.J.B. Wood, W.H. Holzapfel (Eds.), The Genera of Lactic Acid Bacteria, vol. 2, Chapman \& Hall, London, pp. 327-367.

12. Lopez-Diaz T. M., Alonso C., Roman C., Garcia-Lopez M., Moreno B. (2000), Lactic acid bacteria isolated from a hand-made blue cheese, Food Microbiology, 17, pp. 23-32.

13. Bulut, Ç., Günes, H., Okuklu, B., Harsa, S., Kılıç, S., Çoban H.S., Yenidünya, A.F. (2005), Homofermentative lactic acid bacteria of a traditional cheese, Çömlek Peyniri from cappadocia region, Journal of Dairy Research, 72, pp. 19-24.

14. Cheriguene, A., Chougrani, F., Bekada, A.M.A., El Soda, M., Bensoltane, A. (2007), Enumeration and identification of lactic microflora in Algerian goat's milk, African Journal of Biotechnology, 6(15), 1854-1861.

15. Guley Z. (2008), Doğal üretilen küflü peynirden izole edilen bazı laktik asit bakterilerinin aflatoksin B1 ve aflatoksin M1 üzerine etkisinin araştırılması, Ege Üniversitesi Fen Bilimleri Enstitüsü, (Doktora Tezi), İzmir. (in Turkish)

16. Reuter G. (1995), Culture media for enterococci and group D streptococci. In: Culture Media for Food Microbiology Progress in Industrial Microbiology Ed. Corry, J.E.L., Curtis, G.D.W. and Baird, R.M. pp. 51-61. Philadelphia, PA: Elsevier Health Sciences.

17. Kilic S. (1986), Orijini, özellikleri, oranları farklı L. bulgaricus ve S. thermophilus bakterileri içeren sıvı, dondurulmuş ve liyofilize kültürler ile yapılan yoğurtların nitelikleri üzerine araştırmalar, (Doktora Tezi), İzmir. (in Turkish)

18. Rasic J.I., Kurman J.A. (1978), Cultures and starters - Part III, Chapter, 10, pp. 186-213.

19. Kouker G., Mossel K.E. (1987), Specific and sensitive plate assay for bacterial lipases, Applied and Environmental Microbiology, 53, pp. 211-213. 
20. Leuschner R.G., Kenneally P.M., Arendt E.K. (1997), Method for rapid quantitative detection of lipolytic activity among food fermenting microorganisms. International Journal of Food Microbiology, 37, pp. 237-240.

21. Church F.C., Swaisgood H.E., Porter D.H., Catignani G.L. (1983), Spectrophotometric assay using o-phthaldialdehyde for determination of proteolysis in milk and isolated milk proteins, Journal of Dairy Science, 66, pp. 1219-1227.

22. Bover-Cid S., Holzapfel W.H. (1999), Improved screening procedure for biogenic amine production by lactic acid bacteria. International Journal of Food Microbiology, 53, pp. 33 41.

23. Recsei P.A., Moore W.M., Snell E.E. (1985), Pyruvolyl-dependent histidine decarboxylases from Clostridium perfringens and Lactobacillus buchneri, Journal of Biology and Chemisty, 258, pp. 439-444.

24. Sánchez V.A., Lavilla L.L., Benomar N., Galvez A., Perez P.R., Abriouel, H. (2013), Phenotypic and molecular antibiotic resistance profile of Enterococcus faecalis and Enterococcus faecium isolated from different traditional fermented foods, Foodborne Pathogenesis and Diseases, 10, pp. 143-149.

25. Franz C.M.A.P., Stiles M.E., Schleifer K.H., Holzapfel W.H. (2003), Enterococcin foods a conundrum for food safety, International Journal of Food Microbiololgy, 88, pp. 105-122.

26. Teixeira L.M., Carvalho M.G.S., Facklam,R.R. (2007), Enterococcus. In: Manual of Clinical Microbiology, $9^{\text {th }}$ Edn, ed. P.R. Murray, E.J. Baron, J.H. Jorgensen, M.L. Landry and M.A. Pfaller p. 430. Washington, DC: ASM Press.

27. Garvie E.I. (1984), Taxonomy and Identification of Bacteria Important in Cheese and Fermented Dairy Products, Advances in the Microbiology and Biochemistry of Cheese and Fermented Milk, Eds: Davies, F.L. and Law, B.A., Elsevier Applied Science Publishers London- New York.

28. Teuber M. (1995), The Genus Lactococcus, The Genera of Lactic Acid Bacteria, The Lactic Acid Bacteria, 173-234, Eds: Wood, B.J.B. and Holzapfel, W. H., Vol: 2, Blackie Academic and Professional, an imprint of Chapman \& Hall, Glasgow.

29. Klein G. (2003), Taxonomy, ecology and antibiotic resistance of enterococci from food and the gastro-intestinal tract, International Journal of Food Microbiology, 88, pp. 123-31.

30. Tuncer Y. (2009), Some technological properties of phenotypically identified enterococci strains isolated from Turkish tulum cheese, African Journal of Biotechnology, 8(24), pp. 7008-7016.

31. Dagdemir E., Ozdemir S. (2008), Technological characterization of natural lactic acid bacteria from artisanal Turkish white pickled cheese, International Journal of Dairy Technology, 61(2), pp. 133-140.

32. Suzzi G., Lombardi A., Lanorte M.T., Caruso M., Andrighetto C., Gardini F. (2000), Characterization of autochthonous enterococci isolated from Semicotto Caprino Cheese, a traditional cheese produced in Southern Italy, Journal of Applied Microbiology, 89, pp. 267 274.

33. Jamaly N., Benjouad A., Comunian R., Daga E., Bouksaim M. (2010), Characterization of Enterococci isolated from Moroccan dairy products, African Journal of Microbiology Research, 4(16), pp. 1768-1774.

34. Omafuvbe B.O., Enyioha L.J. (2011), Phenotypic identification and technological properties of lactic acid bacteria isolated from selected commercial Nigerian bottled yoghurt, African Journal of Food Science, 5(6), pp. 340-348.

35. Yildiz O., Otles S. (2010), Peynirde aroma oluşumu: Biyokimyasal bakış, Süt Dünyası Dergisi, 5(28), pp. 54-58. (in Turkish)

36. Durlu-Ozkaya F. (2001), Salamura Beyaz Peynirlerden izole edilen bazı laktokok, enterokok ve laktobasil suşlarının proteolitik aktivite, bakteriyosin ve biyojenamin oluşumu açısından 
karşılaştırılması, Ankara Üniversitesi Fen Bilimleri Enstitüsü, (Doktora Tezi), Ankara. (in Turkish)

37. Yuksekdag Z.N., Beyatli Y. (2003), Kefir mikroflorası ile laktik asit bakterilerinin metabolik, antimikrobiyal ve genetik özellikleri, Orlab OnLine Mikrobiyoloji Dergisi, 1(2), pp. 49-69. (in Turkish).

38. Wallace D.L., Harmon L.G. (1970), Intracellular protease from Streptococcus durans, Journal of Dairy Science, 53, pp. 394-402.

39. Dovat A.M., Reinbold G.W., Hammond E.G., Vedamuthu E.R. (1970), Lipolytic and proteolytic activity of enterococci and lactic group streptococci isolated from young Cheddar cheese, Journal of Milk and Food Technology, 33, pp. 365-372.

40. Carrasco de Mendoza M., Meinardi C.A., Meinardi S.A., Arturo C. (1989), Actividad caseinolitica exocelular de enterococos para starters lácticos, Revista Argentina de Lactología, 2, pp. 27-37. (in Español)

41. Wessels D., Jooste P.J., Mostert J.F. (1990), Technologically important characteristics of Enterococcus isolates from milk and dairy products, International Journal of Food Microbiology, 10, pp. 349-352.

42. Villani F., Coppola S. (1994), Selection of enterococcal strains for waterbuffalo Mozzarella cheese manufacture, Annual Microbiology and Enzimology, 44, pp. 97-105.

43. Andrighetto C., Knijff E., Lombardi A., Torriani S., Vancanneyt M., Kersters K., Swings J., Dellaglio F. (2001), Phenotypic and genetic diversity of enterococci isolated from Italian cheeses, Journal of Dairy Research, 68, pp. 303-316.

44. Sarantinopoulos P., Andrighetto C., Georgalaki M.D., Rea M.C., Lombardi A., Cogan T.M., Kalantzopoulos G., Tsakalidou E. (2001), Biochemical properties of enterococci relevant to their technological performance, International Dairy Journal, 11, pp. 621-647.

45. Yousif N.M.K., Dawyndt P., Abriouel H., Wijaya A., Schillinger U., Vancanneyt M., Swings J., Dirar H.A, Holzapfel W.H., Franz C.M.A.P. (2005), Molecular characterisation, technological properties and safety aspects of enterococci from „Hussuwae, an African fermented sorghum product, Journal of Applied Microbiology, 98, pp. 216-228.

46. Hassaïne O., Zadi-Karam H., Karami N-E. (2008), Phenotypic identification and technological properties of lactic acid bacteria isolated from three breeds dromedary raw milks in south Algeria, Emirates Journal of Food Agriculture, 20(1), pp. 46-59.

47. Belgacem Z.B., Abriouel H., Ben Omar N., Lucas R., MartínezCañamero M., Gálvez A., Manai M. (2010), Antimicrobial activity, safety aspects, and some technological properties of bacteriocinogenic Enterococcus faecium from artisanal Tunisian fermented meat, Food Control, 21, pp. 462-470.

48. Omafuvbe B.O., Enyioha L.J. (2011), Phenotypic identification and technological properties of lactic acid bacteria isolated from selected commercial Nigerian bottled yoghurt, African Journal of Food Science, 5(6), pp. 340-348. 